\title{
Mumps virus infection with laryngeal oedema and thoracic wall phlegmonous inflammation in an adult
}

\author{
Takashi lizuka, ${ }^{1,2}$ Takeshi Kusunoki, ${ }^{1}$ Noritsugu Ono, ${ }^{1}$ Katsuhisa Ikeda ${ }^{1}$
}

${ }^{1}$ Department of

Otorhinolaryngology, Juntendo University Faculty of Medicine, Tokyo, Japan

${ }^{2}$ Department of Otolaryngology, Juntendo University Urayasu Hospital, Urayasu, Japan

\section{Correspondence to}

Dr Takashi lizuka,

t-iizuka@juntendo.ac.jp
To cite: lizuka $\mathrm{T}$,

Kusunoki T, Ono N, et al. BMJ Case Reports Published online: [please include Day Month Year] doi:10.1136/ bcr-2012-007829

\section{DESCRIPTION}

A 27-year-old Bangladeshi complained of fever $\left(39.2^{\circ} \mathrm{C}\right)$ and tenderness of the neck. He was admitted to our hospital. A fiberoptic laryngoscopy revealed oedema of the right side of the epiglottis. A CT scan showed a swelling of the bilateral parotid glands, submandibular glands and the right side of the epiglottis, and the neck and anterior thoracic wall showed phlegmonous inflammation (figure 1). Laboratory tests showed a leucocyte count of $7.2 \times 10^{9} / 1$ (neutrophils $59.1 \%$, lymphocytes $30.4 \%$ and monocytes $6.3 \%$ ), serum amylase of $1250 \mathrm{IU} / \mathrm{l}$ and $\mathrm{C}$ reactive protein of $1.44 \mathrm{mg} / \mathrm{dl}$. $\mathrm{He}$ had not been vaccinated against mumps and had no history of mumps infection. The mumps titre was positive for IgM. The swelling gradually resolved within 3 days and the patient improved without complications by symptomatic therapy.

In Japan, routine mumps vaccination was discontinued in 1933. In previous reports, cases with mumps-related laryngeal oedema were only of adult Japanese because of the high incidence of mumps in Japan. ${ }^{1}$ Only a few countries in Southeast Asia (9\%) and Africa (4\%) use mumps vaccines in their national schedules. ${ }^{2}$ In these areas, there is the possibility of mumps-related laryngeal oedema as in the present case of a Bangladeshi. On the other hand, the UK, the USA, Canada and Ireland have recently had large outbreaks of mumps in young adults in spite of the high use of mumps vaccines $(>94 \%){ }^{2}$ Laryngeal oedema may accompany mumps infection even in non-Japanese people. Therefore, it is necessary to keep the possibility of laryngeal oedema in mind when clinical doctors (including family doctors) encounter patients with mumps.

\section{Learning points}

- Complications by mumps tend to be more severe in adults than in children.

- It is possible to follow laryngeal oedema with mumps infection in the large outbreaks.

\section{Competing interests None.}

Patient consent Obtained.

Provenance and peer review Not commissioned; externally peer reviewed.

\section{REFERENCES}

1 Ishida M, Fushiki H, Morijiri M, et al. Mumps virus infection in adults: three cases of supraglottic edema. Laryngoscope 2006;116:2221-3.

2 Hviid A, Rubin S, Mühlemann K. Mumps. Lancet 2008;371:932-44.

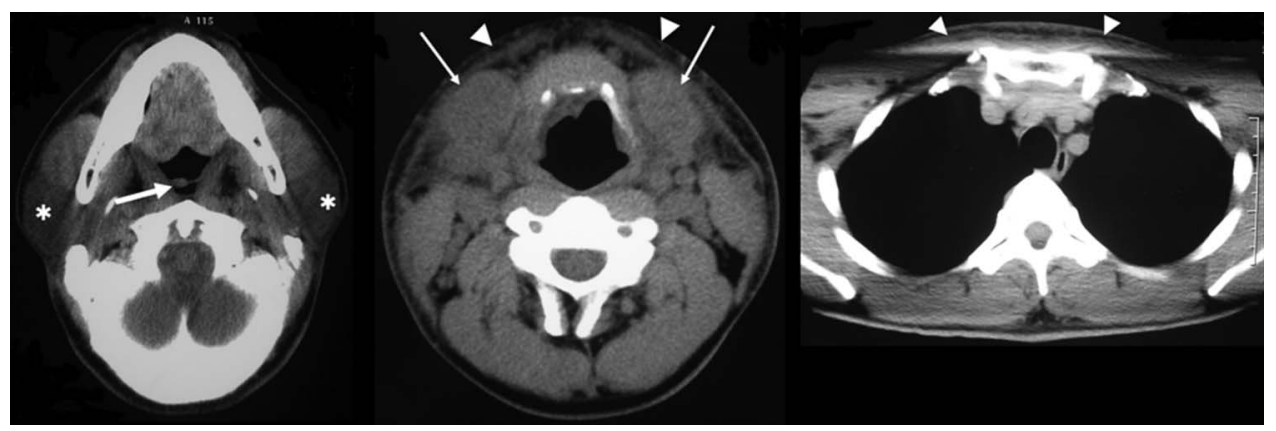

Figure 1 Swelling of the parotid glands (asterisks), submandibular glands (thin arrows) and epiglottis (thick arrows). The neck and anterior thoracic wall reveal phlegmonous inflammation (arrow heads). 
Copyright 2013 BMJ Publishing Group. All rights reserved. For permission to reuse any of this content visit http://group.bmj.com/group/rights-licensing/permissions.

BMJ Case Report Fellows may re-use this article for personal use and teaching without any further permission.

Become a Fellow of BMJ Case Reports today and you can:

- Submit as many cases as you like

- Enjoy fast sympathetic peer review and rapid publication of accepted articles

- Access all the published articles

- Re-use any of the published material for personal use and teaching without further permission

For information on Institutional Fellowships contact consortiasales@bmjgroup.com

Visit casereports.bmj.com for more articles like this and to become a Fellow 